\title{
İçme Suyu Dağıtım Sistemlerinde Su Kayıplarının Azaltılması: Kocaeli Örneği
}

\section{Burak Kızılöz',}

${ }^{1}$ Kocaeli Büyükşehir Belediyesi, ISU Genel Müdürlüğü, Çevre Koruma ve Kontrol Dairesi Başkanlığı, Gebze, 41400, Kocaeli.

\section{Özet}

Su kaynakları klsıtlı olan idareler için içme suyu dağıtım sistemlerinde görülen yüksek seviyelerdeki su kayıpları ciddi bir problemdir. Bu kayıplar, ancak şebekenin izlenmesi, kontrol edilmesi ve doğru bir şekilde yönetilmesi ile azaltılabilir. Bu çalışmada Kocaeli'nin merkez ilçesi olan İzmit'in mevcut içme suyu varlıkları sayısallaştırılarak hidrolik model yardımıyla yüksek seviyelerde seyreden su kaybının azaltılması amaçlanmıştır. Bu amaç için ilk olarak toplam şebeke uzunluğu $1143 \mathrm{~km}$ olan İzmit'in $567,95 \mathrm{~km}$ 'sinde 69 izole ölçüm bölgesi olușturulmuştur. Her izole bölge içinde aktif sizıntı kontrol yöntemleri uygulanarak tespit edilen 2116 șüpheli sızmadan 684 'ü onarılarak kayıplar azaltılmıştır. İkinci olarak tespit edilemeyen sızmaları önlemek için basınç kırıcı vanalar kullanılarak basınç yönetim sistemi uygulanmıstır. Aktif sızıntı kontrol metotları ve basınç yönetim aktiviteleri sonrasında minimum gece debisinde yaklașlk 192,48 l/s 'lik azalma elde edilmiştir. Üçüncü olarak, izole bölge içinde ekonomik ömrünü tamamlamış su sayaçları yenilenerek idari kayıplar da düşürülmüşü̈r. Sonuç olarak İzmit'in 2014 yılında \%45,40 olan su kaybı 2019 yılında \%29,50 seviyelerine kadar indirgenebilmiştir. Bu çalışmada uygulanan aktif sızıntı kontrolü, basınç yönetimi ve sayaç değişimi metotlarının diğer ilçelere de uygulanarak Kocaeli genelinde su kaybının azaltılması ve 2014 yılında yayımlanan yönetmelik gereği su kaybının \%25 seviyesine düşürülmesi hedeflenmiştir.

\section{Anahtar Sözcükler}

Su Kaybı, Minimum Gece Debisi, Basınç Yönetimi, İzole Bölge, Kocaeli

\section{Reducing Water Losses in Potable Water Distribution Systems: A Case Study of Kocaeli}

\begin{abstract}
Water utilities with limited water resources have difficulties arising from high levels of water losses in water supply networks. However, reducing these losses can be possible by monitoring, checking and managing the network correctly. In this study, it is aimed to reduce high levels of water losses through the hydraulic model by digitizing the existing drinking water assets in the central district of Kocaeli, Izmit. In parallel with this purpose, 69 district metered area have been established firstly within $567.95 \mathrm{~km}$ of Izmit with a total network length of $1143 \mathrm{~km}$. In each isolated area, 684 of 2116 suspected leakages have been repaired by using active leakage control methods. Secondly, the pressure management system has been applied by using pressure breaker valves to prevent undetected leakages. A reduction of approximately $192.48 \mathrm{l} / \mathrm{s}$ has been achieved in the minimum night flow after active leakage control methods and pressure management activities. Thirdly, the replacement of end-of-life water meters has contributed to reduce apparent losses in isolated area. In conclusion, the water loss which was $45.40 \%$ in 2014 could be reduced to $29.50 \%$ in Izmit district in 2019. According to the active leakage control, pressure management and meter replacement methods applied in this study, reducing water loss to $25 \%$ throughout Kocaeli is possible by using these methods in other districts.
\end{abstract}

\section{$\underline{\text { Keywords }}$}

Water Loss, Minimum Night Flow, Pressure Management, Isolated Area, Kocaeli

\section{Giriş}

Ekonomik gelişmenin etkisiyle büyükşsehirlerde nüfusun artması ve buna paralel olarak mevcut su kaynaklarının ihtiyacı karşılayamaması, alternatif su kaynakları arayışı ve su dağıtım sistemlerinde gerçekleşen yüksek seviyelerdeki kayıplar idarelerin çözmesi gerektiği önemli konulardır. Su kayıplarını azaltacak yöntemleri uygulamak ve geliştirmek yeni su kaynak arayıșlarına göre daha ekonomiktir. Ülkemizde kayıplarının azaltılması konusunda su idareleri önemli çalıșmalar yapmaktadır. İdareler çoğunlukla fiziki kayıpları azaltmak için su dağıtım sistemlerini yönetilebilir ve kontrol edilebilir izole ölçüm bölgelerine ayırma (Boztaş vd. 2019; Durmuşçelebi vd. 2020) ve şebekedeki basıncı düzenleyen basınç yönetim sistemi (Güngör vd. 2019) uygulamalarını tercih etmektedirler. Ayrıca idari kayıpları azaltmak için ekonomik ömrü dolmuş su sayaçlarının (Yılmaz vd. 2019) yenisi ile değiştirilmesi gereklidir. İdareler, su dağıtım sistemlerindeki fiziki ve idari kayıpları önleyici çalışmaları bir arada uygulayarak kayıplarını daha hızlı bir şekilde azaltabilirler. 
Gelir getirmeyen su kaybının dünya genelinde günlük 346 milyon $\mathrm{m}^{3}$ ve yıllık 126 milyar $\mathrm{m}^{3}$ olduğu tahmin edilir. Bu kayıp su miktarının ekonomik değeri ise yaklaşık 39 milyar dolardır. Dünya genelinde kayıp su miktarının 1/3 oranında azaltılması durumunda kişi başı 150 litre su tüketimi baz alındığında yaklaşık 800 milyon kişinin su ihtiyacı karşılanabilir (Liemberger ve Wyatt 2019). Su kayıplarının önlenmesi su kaynaklarının korunmasına, şebeke işletme maliyetlerinin azalmasına, su kalitesinin artmasına ve enerji maliyetlerinin düşmesine neden olur.

Su kayıp miktarları ülkelerin gelişmişlik seviyelerine göre farlılıklar gösterir. Su kayıp oranları gelişmiş ülkelerde \%8-\%24 seviyelerinde iken gelişmekte olan ülkelerde bu seviye \%24 ile \%45 aralığındadır (OSİB 2017). Ülkemizdeki su idarelerinde 2019 yılı itibarı ile su kayıp oranları İSKI'de \%22,30, ASKI'de \%35,57, İZSU'da \%28,83, BUSKI'de $\% 20,48$, SASKI'de \%51, DİSKI'de \%41,10, Adana-ASKI'de \%37,24, ASAT'da \%45,17, ESKI'de \%28 ve İSU'da \%30 şeklinde gerçekleşmiştir.

Ülkemizde yüksek seviyelerde seyreden su kayıplarını azaltmak, gerekli tedbirleri almak ve belli bir standart oluşturmak için 8 Mayıs 2014 tarihli ve 28994 sayılı Resmî Gazete de "İçme Suyu Temin ve Dağıtım Sistemlerindeki Su Kayıplarının Kontrolü Yönetmeliği” yayımlanmıştır. Yönetmeliğin, "İçme-Kullanma Suyu Temin ve Dağıtım Sistemlerinin Yönetimi ve Su Kayıplarının Azaltılması” Bölümü, 6 (1-b) maddesinde, idarelerin su ve bütçe ihtiyaçlarını belirlemesi, fayda ve maliyet analizlerini hazırlaması ve stratejik planlarında su kayıplarını azaltıcı yöntemleri uygulaması ifade edilmiştir. Bununla birlikte idareler su kayıp oranlarını, bu yönetmeliğin yürürlük tarihinden itibaren, büyükşehir ve il belediyelerinde 5 yıl içerisinde en fazla \%30, takip eden 4 yıl içerisinde ise en fazla \%25 düzeyine; diğer belediyelerde 9 yıl içerisinde en fazla \%30, takip eden 5 y1l içerisinde ise en fazla \%25 düzeyine indirmekle yükümlü olmuşlardır.

Amerikan Su İşleri Birliği (American Water Works Association-AWWA) ve Uluslararası Su Birliği (International Water Association-IWA) tarafından 2003 yılında su dağıtım sistemindeki su denge birleşenleri tanımlanarak standartlaştırılmıştır (AWWA 2003). Bu terminoloji’ ye göre su kaybı, idari ve fiziksel su kayıplarından oluşmaktadır. İdari kayıplar, sayaçlardaki ölçüm hataları ve izinsiz tüketimi içerir. Genel prensip olarak idari kayıpların önlenmesi için su sayaçlarının yaşı ve sayaçtan geçen toplam su miktarı kriterleri dikkate alınarak değiştirilmesi su idareleri tarafından uygun görülür (Davis 2005; Thornton vd. 2008). İdari kayıpların, su idarelerinin alacağı yönetim kararları ve sahada yapılacak sıkı denetimler ile azaltılması fiziksel kayıplara göre daha kolay olacaktır.

Fiziki kayıplar su dağıtım sistemindeki iletim, dağıtım, depo ve abone bağlantılarındaki sızmalardan kaynaklanır. Su kaybı konusu literatürde pek çok araştırmacı tarafından çalışılmıştır. Kanakoudis ve Muhammetoğlu (2014) Antalya (Türkiye) ve Kos (Yunanistan) içme suyu şebeke sistemlerinde izole bölgeler ve basınç yönetim sistemi uygulayarak fiziki kayıpları azaltmaya çalışmışlardır. Özellikle aktif sızıntı kontrol metodu ve basınç yönetim sistemi kullanılarak minimum gece debileri önemli ölçüde azaltılmıştır. Gonelas ve Kanakoudis (2016) Yunanistan’ın, Kozani su dağıtım sisteminde yirmi dört izole ölçüm bölgesi oluşturarak ve on iki adet basınç kırıcı vana kullanarak beş farklı senaryo için hidrolik model tasarlamışlardır. Uygulanan basınç yönetimi ile sisteme giren yüksek seviyelerdeki su miktarlarında azalma sağlamışlardır. Samir vd. (2017) Mısır'ın, Arama izole bölgesinde WaterCAD hidrolik model programı ile farklı senaryolar geliştirerek ve basınç kırıcı vanaları kullanarak sızmayı minimize etmeye çalışmışlardır. Basıncın düşürülmesi ile birlikte izole bölge içinde ki sızma miktarı \%37 seviyelerine kadar azaltılmıştır. Boztaş vd. (2019) Malatya'nın içme suyu dağıtım sisteminde aktif sızma kontrolü ve minimum gece debisi izleme yöntemlerini kullanarak servis bağlantılarının su kaybı üzerindeki etkisini araştırmışlardır. Bununla birlikte su dağıtım sistemini 14 izole bölgeye (DMA) ayırarak su kayıp modeli kurmuşlardır. Ayrıca aktif sızma kontrolü yöntemi ile 336 adet olası sızma noktasını belirleyerek bunların 239 tanesinde fiili sızma tespit etmişlerdir. Bu sızmaların \%77,4'ü servis bağlantılarından \%22,6'sı ise ana şebeke arızalarından kaynaklanmıştır. Tüm sızmaların onarımının yapılması ile toplam 148,9 1/s'lik su kaybını önlemişlerdir. Durmuşçelebi vd. (2020) bir su dağıtım sisteminde kayıpları azaltmak, kontrol etmek ve yönetebilmek için izole bölgelerin önemini vurgulamışlardır. Çalışma alanı olarak seçilen MASKI'nin başlangıçta \%60 olan su kayıp seviyeleri \%30-40 sevilerine kadar düşürülmüştür. Güngör vd. (2019) Denizli’nin su dağıtım sisteminde dört izole bölge seçerek basınç kırıcı vanalar ile basınç yönetim sistemi uygulamışlardır. Çalışma başlangıcında 40-63m aralığında değişen şebeke basıncı çalışma sonunda 28-45m aralığına kadar azaltarak toplamda 5,78 1/s'lik su kazanımı elde etmişlerdir. Arabacı ve Dursun (2019) Konya'nın içme suyu şebeke sisteminde hidrolik model çalışması ve saha uygulamaları yaparak izole alt bölgede başlangıçta 34 1/s olan gece debisini 20 1/s'ye kadar düşürmüşlerdir. Koşucu vd. (2021) Epanet 2 yazılım programını kullanarak oluşturdukları hipotetik model yardımıyla bir su dağıtım sisteminde klasik basınç yönetimi ile gerçek zamanlı basınç yönetimini karşılaştırarak su kaybını analiz etmişlerdir. Model sonucunda gerçek zamanlı basınç yönetimi ile günlük $7,1 \mathrm{~m}^{3}$ 'lük daha fazla su tasarrufu elde edilmiştir. İyi işletilen ve yönetilen su şebeke sistemlerinde uzmanların tecrübelerine dayanılarak fiziki kayıpların ana şebekelerden ziyade genellikle servis bağlantılarından kaynaklandığı belirtilir (Lambert ve Morrison 1996). İdari kayıplar için literatürde genellikle sayaçlar üzerine odaklanılmıştır. Dünya genelinde mesken tipi sayaçların ekonomik ömürlerinin 5-10 yıl arasında olduğu yaygın bir kabuldür (Lambert 2002). Yılmaz vd. (2019) Malatya İli sınırları içinde gelir getirmeyen su miktarını azaltmak için mesken tipi sayaçların en uygun değişim sürelerini incelemişlerdir.

Yukarıda bahsedilen literatür çalışmaları incelendiğinde su kayıpları için çoğunlukla fiziki kayıplar üzerine odaklanıldığı görülmektedir. Bu tür kayıpları azaltmak için de izlenilen temel yöntemler izole bölge tasarımı (Boztaş vd. 2019; Durmuşçelebi vd. 2020) ve basınç yönetim sistemidir (Güngör vd. 2019; Koşucu vd. 2021). Bu çalışmada ise fiziki ve idari kayıpları azaltıcı yöntemler bir arada uygulanarak su kayıplarının sistemli bir şekilde düşürülmesi amaçlanmıştır. 
Bu kapsamda İzmit'in su dağıtım şebekesi altmış dokuz izole bölgeye ayrılarak basınç yönetim sistemi oluşturulmuş ve SCADA sistemi ile şebeke online olarak izlenmiştir. Ayrıca izole bölge içindeki ekonomik ömrünü tamamlayan su sayaçları yenilenerek su kayıpları üzerinde etkili olan tahakkuk kayıpları da engellenmiştir. İzmit su dağıtım sisteminde uygulanan çalışmaların Kocaeli’nin tamamına uygulanarak su kayıplarının 2023 yılında \%25 seviyesine düşürülmesi hedeflenmektedir.

\section{2. Çalışma Alanı}

Kocaeli Büyükșehir Belediyesi, Kocaeli Su ve Kanalizasyon İdaresi Genel Müdürlüğü (İSU) hizmet alanı içinde bulunan İzmit ilçesi çalışma alanı olarak seçilmiştir. Merkez ilçe olan İzmit, Kocaeli’nin nüfus yoğunluğu bakımından ikinci büyük ilçesi olup, yüz ölçümü 58,04 km²'dir (Şekil 1). 2019 yılında ilçenin su tüketimi $31.365 .786 \mathrm{~m}^{3}$ ve toplam abone sayısı ise 163.895 olarak gerçekleşmiştir. Bu abonelerin 466 tanesi yüksek tüketim abonesi olup, 15'i konut, 180'i işyeri, 32'si sanayi, 169'u resmi, 56's1 KSUB, 6's1 inşaat ve 8'i geri kazanım suyundan oluşmaktadır (ISSU 2019). Bölgenin toplam içme suyu şebeke uzunluğu $1143 \mathrm{~km}$, servis hattı uzunluğu 548,41 km ve yapımı tamamlanan izole bölge hat uzunluğu ise 567,95 km'dir. İlçenin altyapısı farklı çap ve uzunluklardaki asbest $(\% 0,43)$, çelik $(\% 4,52)$, galvaniz (\%0.09), polietilen $(\% 51,28)$, pik $(\% 0,51)$, düktil demir $(\% 18,60)$ ve PVC $(\% 24,57)$ borulardan oluşmaktadır. En yaygın olan boru cinsleri $601 \mathrm{~km}$ ile polietilen (PE) ve 288,84 km ile PVC borulardır. İzole bölge çalışmaları halen devam etmektedir.

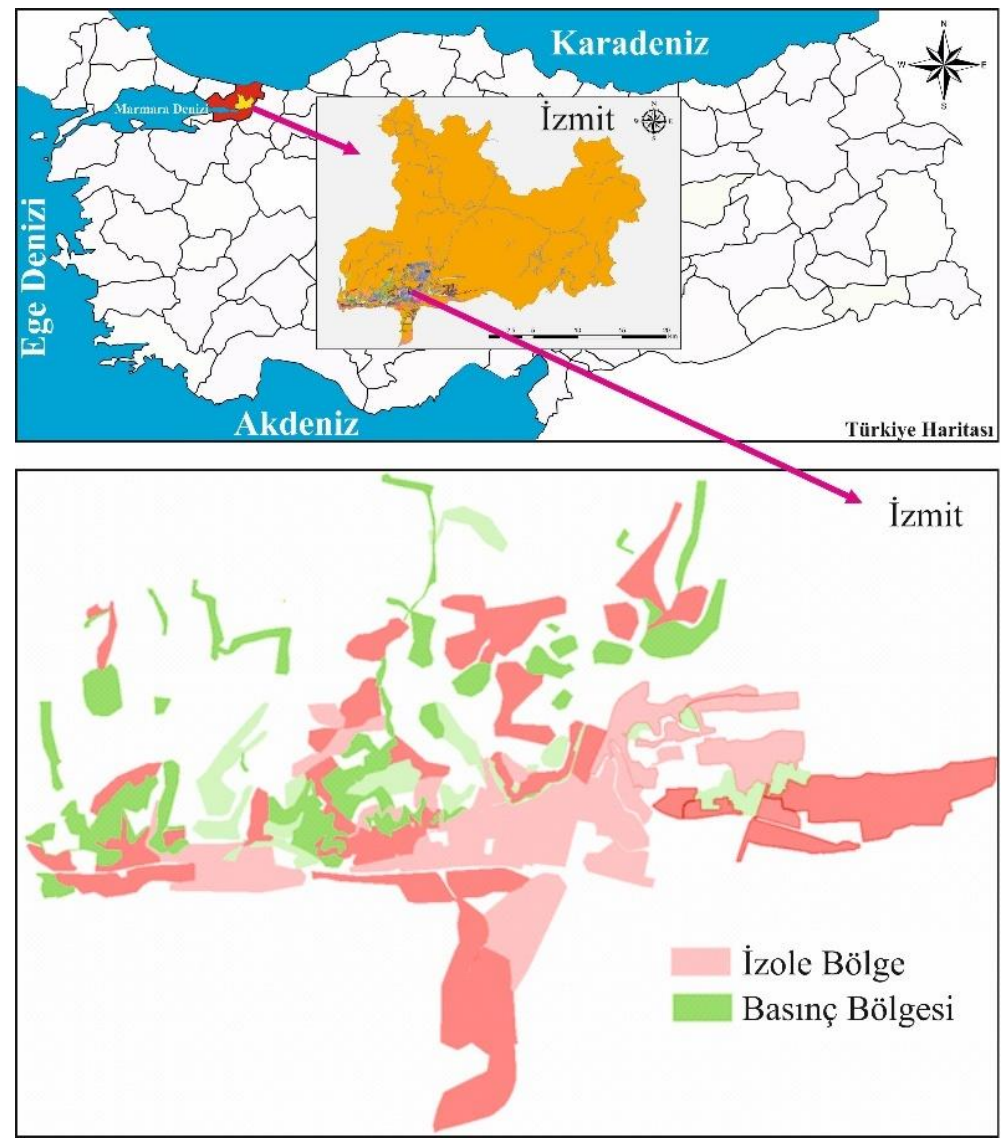

Şekil 1: Kocaeli ve çalışma alanı haritası

\section{Yöntem}

\subsection{Su Dengesi}

Amerikan Su İşleri Birliği (American Water Works Association-AWWA) ve Uluslararası Su Birliği (International Water Association-IWA) tarafından 2003 yılında önerilen standart su denge tablosu (AWWA 2003) kullanılarak İzmit su dağıtım sisteminin gelir getiren ve gelir getirmeyen su miktarı yüzdeleri hesaplanmıştır (Tablo 1). Aynı zamanda su kaybı bir performans indikatörü olup, idari ve fiziki kayıpları içerir. İdari kayıplar, izinsiz tüketim ve sayaçlardaki ölçüm hatalarından, fiziki kayıplar ise temin ve dağıtım hatları ile servis bağlantılarında oluşan kayıp-kaçaklar ve depolarda meydana gelen kaçak ve taşmalardan oluşur. 
Tablo 1'de 2019 yılında İSU Genel Müdürlüğü hizmet sahasında bulunan İzmit ilçesinin su dağıtım sistemine giren toplam su miktarının 31.365.786 $\mathrm{m}^{3}$ olduğu görülmektedir. Burada gelir getiren su, sisteme giren suyun \%69,80'i ve gelir getirmeyen su miktarı ise \%30,20'sidir. Gelir getirmeyen su oranı ise faturalandırılmamış izinli su tüketimi ve su kayıplarını içerir. İzmit'in faturalandırılmamış izinli su tüketimi \%1 seviyesinin altındadır. Bunun en önemli nedeni şebekede aktif sızıntı kontrol metodu ve basınç yönetiminin uygulanarak sızmaların azaltılmasıdır. İzmit'in içme suyu şebekesinin kontrol altına alınarak sızmaların önlenmesi ile faturalandırılmamış ölçülmemiş kullanımın \%0,12 seviyelerine kadar indirilmiştir. Ayrıca İSU tarafından sahada yapılan sıkı denetimler sonucunda ücretsiz olan halk çeşmeleri, ibadethaneler, mezarlıklar vb. aboneleştirilerek su tüketimleri tahakkuk altına alınarak faturalandırılmamış ölçülmüş kullanım oranı \%0,58'e düşürülmüştür.

2019 yılı içerisinde gelir getirmeyen su miktarı içerisinde en fazla kayıp oranı \%25,33 ile fiziki kayıplarda gerçekleşmiştir. Fiziki kayıplar idarelerin üzerinde durduğu önemli bir problemdir. İdareler, bu problemin üstesinden gelmek için şebekede kat ayrımlarının oluşturularak depo besleme alanlarının sınırlandırılması, izole ölçüm bölgeleri oluşturarak tek noktadan su girişinin sağlanması ve minimum gece debisinin SCADA sistemi ile online izlenmesi, akustik dinleme cihazları ile arızaların tespit edilerek onarılması, sürekli arıza veren ekonomik ömrünü doldurmuş şebekelerin ve abone bağlantılarının yenilenmesi ve basınç yönetim sistemi uygulayarak ideal işletme basıncının sağlanması ile arızaların azaltılması, gibi çalışmalar yapmaktadırlar. Bu çalışmada İSU tarafından işletilen $1143 \mathrm{~km}$ olan içme suyu şebekesinin 567,95 km'sinde izole ölçüm bölgeleri oluşturularak basınç yönetimi uygulanmış ve İzmit'in genel su kaybı oranı \%29,50 seviyelerine düşürülmüştür. İzole bölge çalışmaları halen devam etmekte olup, ilçenin tamamına uygulanması planlanmaktadır. Ayrıca İzmit genelinde merkez ve kırsalda toplam 156 adet içme suyu deposu bulunmaktadır (İSU 2019). Bu depoların yaklaşık 100 tanesinin giriş, çıkış debileri ve taşkın seviyeleri SCADA sistemi ile takip edilmektedir. Mevcut depoların iç izolasyonları yapılarak sızdırmazlıkları sağlanmıştır. Böylece depolarda meydana gelen kaçak ve taşmalar \%0,18’e kadar düşürülmüştür.

İdari kayıplar ile mücadele etmek fiziki kayıplara göre daha kolaydır. İdari kayıplar, izinsiz tüketim ve sayaçlardaki ölçüm hatalarından meydana gelmektedir. İSU tarafından teknik ekiplerce yapılan denetimler sonucunda abonesiz sayaçlar ve yasal olmayan bağlantılar tespit edilip aboneleştirilerek izinsiz tüketim oranı 2019 y1lı sonunda \%0,90'a düşülmüştür. Ayrıca 2014 yılında başlayan hidrolik model çalışması ile birlikte tasarlanan izole ölçüm bölgeleri içinde ekonomik ömrü dolan sayaçlar ileride uzaktan okumaya entegre olabilecek volumetrik tipte sayaçlar ile değiştirilmiştir. Toplam sayaç sayısı 163.895 olan ilçede toplam 136.785 sayaç yenilenmiştir. Sayaç montaj kurallarının doğru bir şekilde uygulanması sonucunda sayaç ölçüm hataları \%3,26’ya düşürülmüştür. İzole ölçüm bölge uygulamalarının ve sayaç yenileme çalışmalarının devam etmesi ile birlikte sayaçlardaki ölçüm hatalarının \%1 seviyesinin altına indirilmesi İSU tarafindan planlanmaktadır.

Tablo 1: Izmit için 2019 yılı su denge tablosu

\begin{tabular}{|c|c|c|c|c|c|}
\hline \multirow{4}{*}{$\begin{array}{l}\text { Sisteme } \\
\text { Giren } \\
\mathrm{Su}\end{array}$} & & $\begin{array}{l}\text { Faturalandırılmış } \\
\text { izinli su tüketimi }\end{array}$ & $\begin{array}{l}\text { Faturalandırılmış ölçülmüş } \\
\text { kullanım }\end{array}$ & $\% 69,57$ & $\begin{array}{l}\text { Gelir getiren } \\
\text { su miktarı }\end{array}$ \\
\hline & $\begin{array}{l}\text { İzinli } \\
\text { Tüketim }\end{array}$ & $\% 69,80$ & $\begin{array}{l}\text { Faturalandırılmış ölçülmemiş } \\
\text { kullanım }\end{array}$ & $\% 0,23$ & $\% 69,80$ \\
\hline & $\% 70,50$ & $\begin{array}{l}\text { Faturalandırılmamış } \\
\text { izinli su tüketimi }\end{array}$ & $\begin{array}{l}\text { Faturalandırılmamış ölçülmüş } \\
\text { kullanım }\end{array}$ & $\% 0,58$ & \multirow{6}{*}{$\begin{array}{l}\text { Gelir getirmeyen } \\
\text { su miktarı }\end{array}$} \\
\hline & & $\% 0,70$ & $\begin{array}{l}\text { Faturalandırılmamış } \\
\text { ölçülmemiş kullanım }\end{array}$ & $\% 0,12$ & \\
\hline \multirow{4}{*}{$31.365 .786 \mathrm{~m}^{3}$} & \multirow{4}{*}{$\begin{array}{l}\text { Su } \\
\text { kayıpları } \\
\% 29,50\end{array}$} & İdari kayıplar & İzinsiz tüketim & $\% 0,90$ & \\
\hline & & $\% 4,16$ & Sayaçlardaki ölçüm hataları & $\% 3,26$ & \\
\hline & & Fiziki kayıplar & $\begin{array}{l}\text { Temin ve dağıtım hatları ile } \\
\text { servis bağlantılarında oluşan } \\
\text { kayıp-kaçaklar }\end{array}$ & $\% 25,15$ & \\
\hline & & $\% 25,33$ & $\begin{array}{l}\text { Depolarda meydana gelen } \\
\text { kaçak ve taşmalar }\end{array}$ & $\% 0,18$ & \\
\hline
\end{tabular}

\section{2. İzole Ölçüm Bölgeleri}

Bir su dağıtım sistemindeki su kayıplarını azaltmak, sızmaları tespit etmek ve gece debisini izleyebilmek için tek noktadan şebekeye su girişi sağlanarak ölçülebilir izole alanlar oluşturulur. Etkili bir su kayıp yönetiminde küçük izole alan uygulamaları tercih edilir (Rahman ve Wu 2018). Bu alanların tasarımında şebeke uzunluğu, servis bağlantı sayısı, abone sayısı ve işletme maliyeti oldukça önemlidir. Tasarım aşamasında servis bağlantı sayısı fazla olan alanlarda ana kriter olarak şebeke uzunluğu yerine servis bağlantı sayısının kullanılması daha uygundur (Durmuşçelebi vd. 2020). İdeal servis bağlantı sayısının 500 ile 3000 arasında olması önerilir (Morrison vd. 2007; Mutikanga 2013). Ayrıca izole bölge sınırları tasarlanırken arazi eğiminin dikkate alınması gerekir (Morrison vd. 2007; Mutikanga 2013). 
Tasarımda arazi eğimi dikkate alınmadığı zaman izole bölge sınırları içinde bulunan kritik noktadaki meskende düşük basınç problemi oluşur. Bu neden ile her zaman en üst noktadaki meskene göre basınç yönetimi düzenlenmelidir. Bununla birlikte izole bölge içindeki su kayıp miktarının doğru bir şekilde belirlenebilmesi için abone sayaçlarının sisteme tanımlanması, online izlenmesi, arızalı ve ekonomik ömrü dolmuş sayaçların değiştirilmesi ve temin ile tahakkuk okumalarının eş zamanlı olarak gerçekleşmesi gerekmektedir.

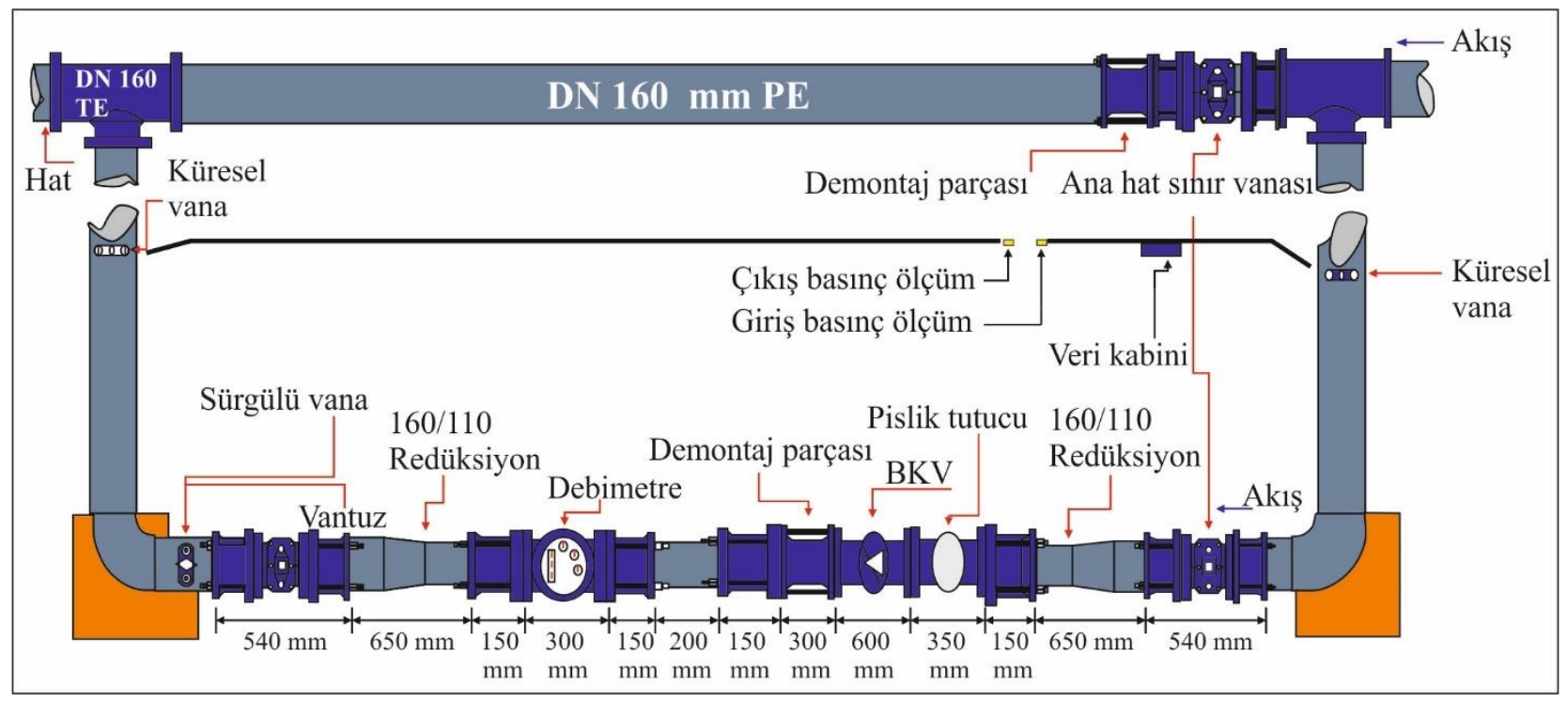

Şekil 2: Izmit su dağıtım sistemindeki İB67 odası

\subsection{Basınç Yönetim Sistemi}

Su dağıtım hatlarında ve birleşenlerinde (servis bağlantısı, vana, flanş, dirsek, hidrant, bağlantı parçaları, vb.) sızmaları azaltmak için kullanılan basınç yönetimi etkili bir metottur (Farley ve Trow 2003; Lambert vd. 2013). Bir su dağıtım sisteminde sızmalar, arka plan sızıntısı, ihbar edilen sızıntı ve ihbar edilmeyen sızıntı şeklinde gerçekleşir (Farley 2003; Lambert 2003).

İhbar edilmiş sızıntılar yüzeye çıkan ve gözle görülen sızıntılar olurken ihbar edilmemiş sızıntılar ise yüzeye çıkmayan, gözle görülemeyen ancak akustik dinleme cihazları ile tespit edilebilen sızıntılardır. Basınç yönetim sistemi uygulamalarında amaç akustik cihazlar ile belirlenemeyen arka plan sızıntılarını azaltmaktır. Basınç yönetim sisteminin en önemli avantajı ise ideal işletme basıncını sağlayarak arıza sayılarını azaltmak ve şebeke birleşenlerinin ekonomik ömürlerinin uzamasını sağlamaktır.

Arazi topografyası, abone tüketim alışkanlıkları ve şebeke karakteristikleri benzer olan alanlar için basınç yönetiminin uygulanması faydalıdır. Sabit çıkışı, zamana duyarlı, kritik noktaya göre çalışan ve debiye duyarlı olmak üzere dört tip basınç yönetim sistemi bu çalışmada kullanılmıştır.

\section{Uygulama}

\section{1. İçme suyu varlıklarının tespiti}

İzmit ilçesinde bilinmeyen ve kayıt altına alınmayan mevcut içme suyu varlıklarının yeri, çapı ve malzeme cinsinin tespiti için yeraltı GPR radarları ve boru dedektörleri kullanılmıştır. Sahada doğrulama kazısı yapıldıktan sonra tespit edilen varlıklar koordinatlı bir şekilde CBS’ye (Coğrafi Bilgi Sistemi) aktarılarak sayısallaştırılmıştır (Şekil 3). 

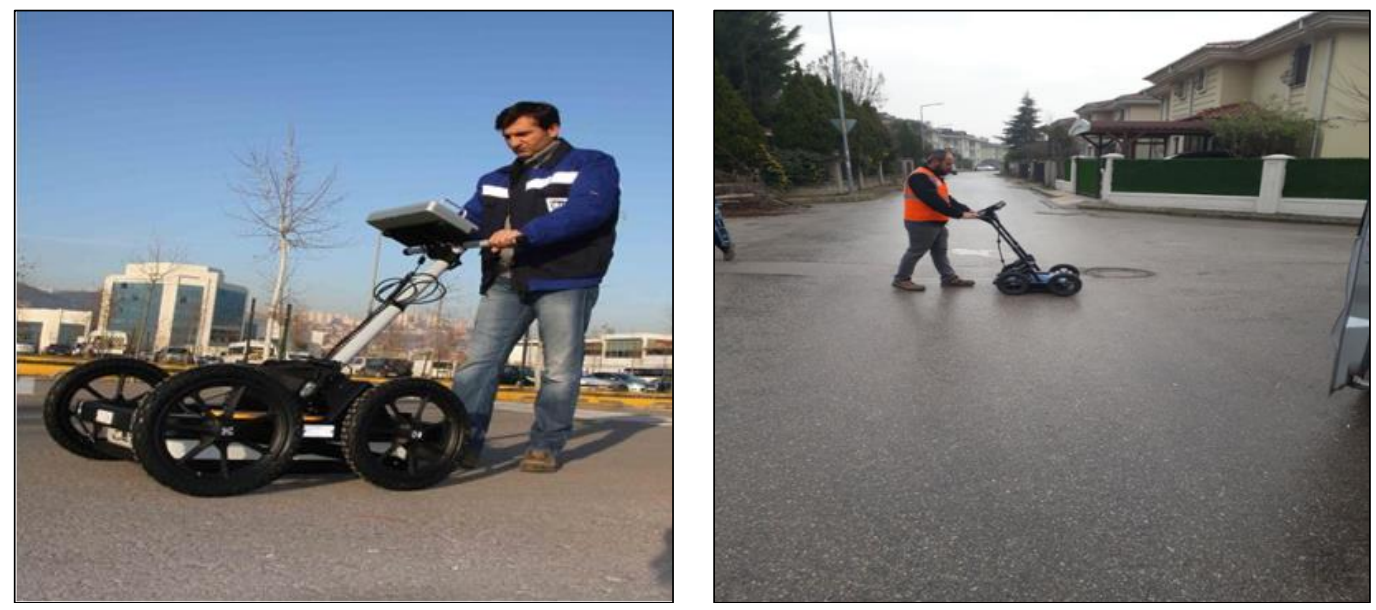

Şekil 3: ISU tarafından yapılan içme suyu varlıklarının tespiti

\section{2. İzole ölçüm alanları}

İzmit'in su dağıtım şebekesini yönetebilmek ve izleyebilmek için 69 adet alt izole bölge odası inşa edilerek her bir oda debimetre, basınç kırıcı vana (BKV) ve veri kaydediciler ile donatılmıştır (Şekil 4).
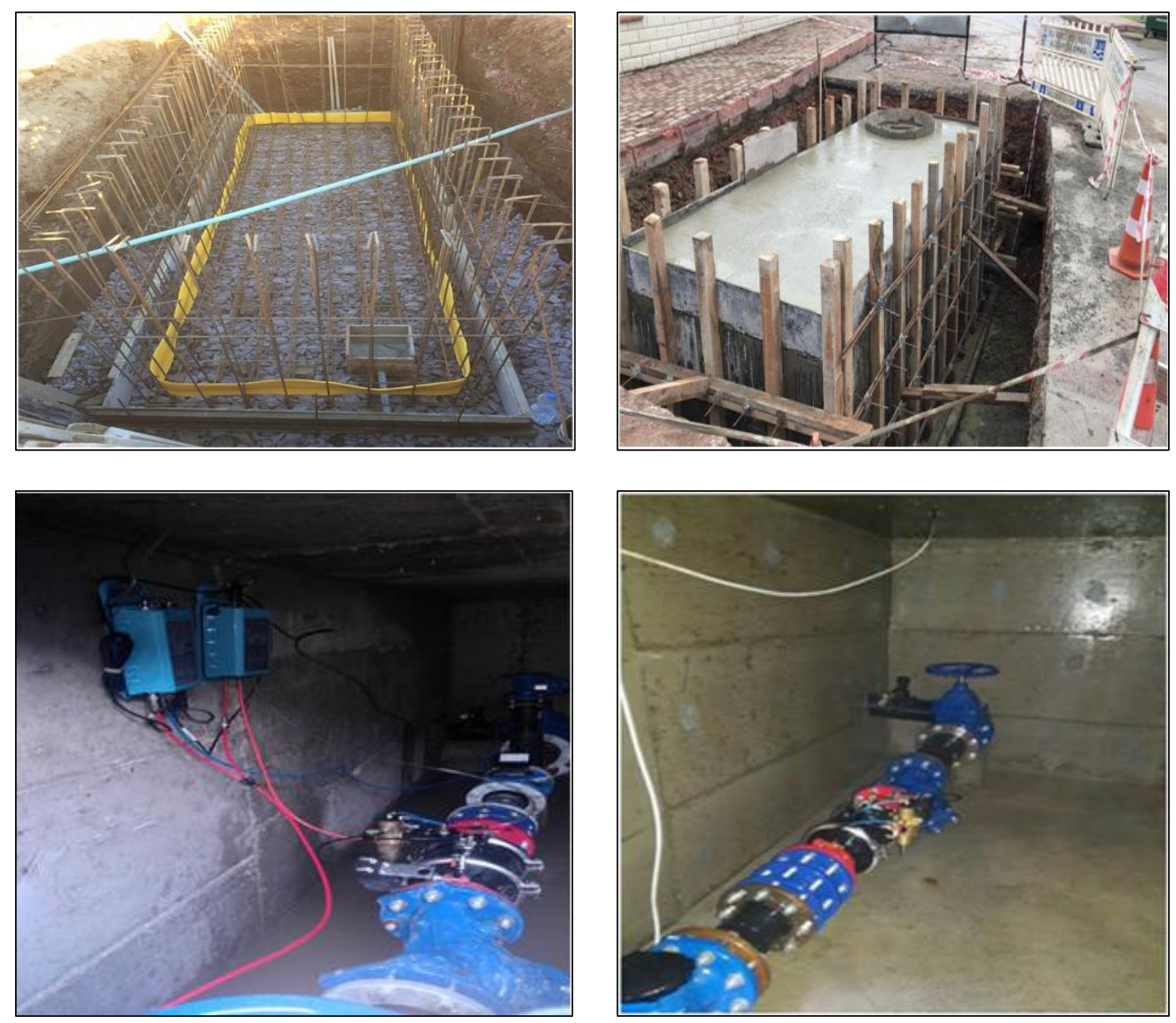

Şekil 4: Izole ölçüm bölge odaları (Görmüş 2017)

İzole ölçüm bölge sınırları içinde en uç noktadan başlayarak ve debi çıkışları kontrol edilerek tüm vanaların sırayla kapatılması ile adım testi uygulanmıştır. Bu test süresince su basıncının sıfır olması sağlanmıştır. Su kayıplarını azaltmak için SCADA sistemi yardımıyla tüm izole bölgelere giren debi 24 saat boyunca sürekli izlenmiştir. Bununla birlikte bölgenin günlük su debisinde artış olması durumunda akustik dinleme cihazları ile aktif sızıntı kontrolü yapılarak yüzeye çıkmayan arızalar tespit edilmiş ve su kayıpları önlenmiştir (Şekil 5). 


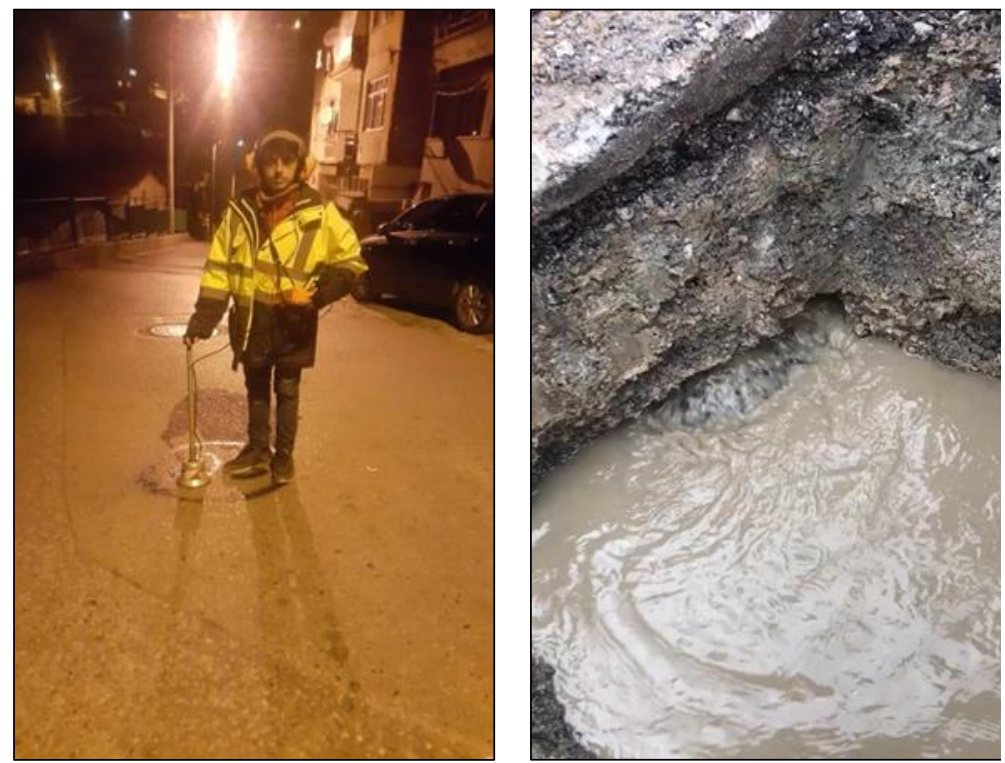

Şekil 5: ISU tarafından yapılan arıza tespit çalışması

Tablo 2'de tüm izole bölgelere ait şebeke uzunluğu, şebeke yaşı ile abone, servis bağlantı ve arıza sayıları verilmiş̧ir. Tablo 2 incelendiğinde en yaşlı izole bölge 25,71 yıl ile İB27 olup, ortalama izole bölge yaşı ise 11,74 yıldır. En uzun şebeke 38,18 km ile İB6'da ve en kısa şebeke uzunluğu ise $0,43 \mathrm{~km}$ ile İB35'de görülmektedir. İzole bölgelerdeki abone sayıları 9-4772 aralığında servis bağlantı sayıları ise 1-955 aralığında değişmektedir. Toplam 567,95 km olan izole bölge şebekesinde 2116 adet şüpheli arıza tespit edilerek 684'nün onarımı yapılmıştır. Bu arızaların 206 adeti (yaklaşık \%30) ana şebeke ve 478 adeti (yaklaşık \%70) servis bağlantı arızalarından oluşmaktadır. Tablo 2'de sunulan ihbar edilmemiş sızıntılar karşılaştırıldığında servis bağlantılarından kaynaklanın ihbar edilmemiş sızıntı oranlarının \%70 ile oldukça yüksek olduğu görülmektedir. Nicolini vd. (2014), Aydoğdu ve Fırat (2015) ve Boztaş vd. (2019) su dağıtım sistemlerinde yaptıkları çalışmalarda benzer şekilde servis bağlantılarından kaynaklanan sızıntı oranlarını sırasıyla $\% 58, \% 60$ ve $\% 77,4$ gibi yüksek seviyelerde elde etmişlerdir. Servis bağlantılarındaki bu sızıntılar, şebeke ile olan bağlantı noktasından, bu noktadaki bağlantı malzemelerinden, kötü işçilikten, kalitesiz ve basınç dayanımı düşük olan malzeme kullanımından kaynaklanabilir.

Tablo 3'de görüleceği üzere İB41'de basınç yönetim sistemi uygulanmamış ve sadece aktif sızıntı kontrol yöntemiyle (akustik dinleme cihazı kullanılarak) tespit edilen 2 şebeke ve 5 servis bağlantı arızasının onarılması ile minimum gece debisinde 9,06 1/s' lik su tasarrufu sağlanmıştır. Böylece su dağıtım sistemlerinde gerçekleştirilen ihbar edilmemiş sizıntı tespit aktivitelerinin su kayıpları üzerindeki etkisi açıkça görülmektedir.

Tablo 2'ye göre en fazla ihbar edilmemiş sızıntı IB 18'de gerçekleşmiş olup, şebeke arıza oranı \%32 ve servis bağlantı arıza oranı \%68'dir. İB18'in içme suyu şebekesinde 3 asbest, 1 polietilen, 6 pik, 2 PVC ve 4 galvaniz boru arızası oluşurken düktil boruda herhangi bir arıza meydana gelmemiștir. Servis bağlantı arızalarının 19'u galvaniz ve 15'i polietilen boru bağlantılarında gerçekleşmiştir. İdeal şebeke işletiminde ve yönetiminde tek tip boru kullanımı tercih edilmelidir. Çoklu boru kullanımı ambarda ciddi malzeme yoğunluğuna, boru bağlantılarında daha fazla geçiş malzemesine, her cins tamirat aparatının kullanılmasına neden olarak idareleri ekonomik açıdan da zorlayacaktır. Özellikle yeni yapılacak şebeke imalatlarında pik ve asbest boru kullanımlarından kaçınılmalıdır. Her türlü dış darbeye ve yüksek basınca dayanıklı düktil boru kullanımı tercih edilmelidir. İSU Genel Müdürlüğü 2015 yılında aldığı karar ile birlikte içme suyu hatlarında tamamen düktil boru imalatına dönmüştür. Bu tercih, Kocaeli ilinin genel su kayıp oranının 2019 yılı sonunda \%30,2 seviyesine düşmesine katkı sağlamıştır. Abone bağlantılarında galvaniz boru kullanımından kaçınılması ve 16 bar basınca dayanıklı servis bağlantı malzemelerinin tercih edilmesi basınç yönetim sistemi olmayan idarelerde arıza sayısının azalmasında faydalı olacaktır.

İzole bölgelerde ölçülen tüm veriler İSU Genel Müdürlüğü’nün yapmış olduğu ve SCADA sistemi ile entegre edilen İçmesuyu Bilgi Yönetim Sistemi (IBBYS) sistemine online olarak aktarılmış̦tır. Her bir izole bölge içindeki binalar ve su sayaçları İBYS sistemindeki Abone Bilgi Yönetim menüsünde tanımlanmıştır. Böylece her bir bölgenin temin ve tahakkuk karşılaştırmaları sistem üzerinden online olarak yapılarak standart su denge tablosu elde edilmiştir. Eğer standart su denge tablosuna göre izole bölgelerde su kayıp miktarlarında artış görülürse sahada akustik dinleme cihazları ile şüphelenilen noktalarda gece dinlemesi ve su sayacı kaynaklı tahakkuk kayıplarını önleme çalışmaları gerçekleştirilmiştir. 
Tablo 2: Izole ölçüm bölge bilgileri

\begin{tabular}{|c|c|c|c|c|c|c|c|c|}
\hline \multirow{2}{*}{\multicolumn{2}{|c|}{ İzole Ölçüm Bölgeleri }} & \multirow{3}{*}{$\begin{array}{l}\text { Şebeke } \\
\text { uzunluğu } \\
(\mathbf{k m})\end{array}$} & \multirow{3}{*}{$\begin{array}{c}\text { Şebeke } \\
\text { yaşı } \\
\text { (yıl) }\end{array}$} & \multirow{3}{*}{$\begin{array}{c}\text { Abone } \\
\text { sayisı } \\
\text { (adet) }\end{array}$} & \multirow{3}{*}{$\begin{array}{c}\text { Servis } \\
\text { bağlantı } \\
\text { sayısı (adet) }\end{array}$} & \multirow{2}{*}{\multicolumn{3}{|c|}{$\begin{array}{r}\text { Arıza Sayısı (adet) } \\
\text { Onarılan }\end{array}$}} \\
\hline & & & & & & & & \\
\hline No & Konum & & & & & Şüpheli & Şebeke & Abone \\
\hline İB1 & Ersoylu & 10.51 & 12.82 & 985 & 461 & 36 & 4 & 2 \\
\hline İB2 & Gazenfer Bilge & 18.23 & 12.38 & 4772 & 584 & 32 & 3 & 4 \\
\hline İB3 & Cam & 4.09 & 7.7 & 569 & 177 & 10 & 0 & 0 \\
\hline İB4 & Levent & 7.45 & 11.73 & 290 & 163 & 15 & 0 & 2 \\
\hline İB5 & Arızlı & 7.45 & 13.99 & 472 & 193 & 42 & 1 & 0 \\
\hline İB6 & Akpınar & 38.18 & 11.69 & 1864 & 137 & 22 & 0 & 0 \\
\hline İB7 & Sezer & 9.37 & 9.27 & 1423 & 573 & 54 & 3 & 10 \\
\hline İB8 & Akif & 6.69 & 9.72 & 706 & 315 & 56 & 2 & 7 \\
\hline İB9 & Kavaklar & 6.97 & 6.54 & 2225 & 428 & 41 & 0 & 8 \\
\hline İB10 & Kalemcioglu & 10.42 & 5.22 & 3292 & 944 & 58 & 0 & 4 \\
\hline İB11 & Bayrak & 13.53 & 7.23 & 4064 & 955 & 40 & 2 & 10 \\
\hline İB12 & Arda & 8.5 & 5.98 & 1950 & 497 & 36 & 0 & 7 \\
\hline İB13 & Dinamik & 5.19 & 14.29 & 1007 & 303 & 50 & 0 & 13 \\
\hline İB14 & Zengin & 3.84 & 10.99 & 3838 & 459 & 19 & 2 & 0 \\
\hline İB15 & Zengin & 4 & 11.15 & 2424 & 784 & 17 & 8 & 8 \\
\hline İB16 & Doruklar & 5.39 & 11.45 & 3907 & 398 & 10 & 4 & 2 \\
\hline İB17 & Okur & 7.15 & 9.28 & 2420 & 296 & 9 & 0 & 2 \\
\hline İB18 & Ziya Gökalp & 7.07 & 11.02 & 2564 & 296 & 78 & 16 & 34 \\
\hline İB19 & Baycan & 10.64 & 10.68 & 3643 & 754 & 60 & 4 & 40 \\
\hline İB20 & Badem & 5.81 & 16.09 & 1593 & 476 & 11 & 7 & 4 \\
\hline İB21 & Türbebayırı & 8.55 & 9.6 & 2228 & 395 & 28 & 5 & 20 \\
\hline İB22 & Uygar & 7.13 & 11.82 & 1562 & 542 & 80 & 4 & 14 \\
\hline İB23 & Musa Kazım & 3.18 & 4.88 & 1717 & 442 & 12 & 2 & 11 \\
\hline İB24 & Eski Hastane & 2.39 & 11.42 & 793 & 488 & 50 & 12 & 8 \\
\hline İB25 & Narlık Yokuşu & 8.54 & 12.99 & 3446 & 640 & 40 & 12 & 15 \\
\hline İB26 & Sila & 3.58 & 20.64 & 771 & 314 & 15 & 0 & 1 \\
\hline İB27 & Korniş & 6.43 & 25.71 & 1421 & 613 & 48 & 1 & 4 \\
\hline İB28 & Sadettin Yalım & 5.46 & 21.96 & 997 & 370 & 37 & 5 & 17 \\
\hline İB29 & İnönü & 4.84 & 14.2 & 2269 & 318 & 30 & 12 & 17 \\
\hline İB30 & Eski Hamam & 6.97 & 9.38 & 2591 & 425 & 13 & 16 & 23 \\
\hline İB31 & Acisu & 1.61 & 9.71 & 796 & 131 & 38 & 3 & 0 \\
\hline İB32 & İnönü & 3.6 & 7.67 & 1290 & 191 & 20 & 1 & 8 \\
\hline İB33 & Alemdar & 4.66 & 12.41 & 2475 & 408 & 16 & 4 & 7 \\
\hline İB34 & İstiklal & 2.65 & 15.35 & 1024 & 249 & 29 & 4 & 17 \\
\hline İB35 & Seka Hastanesi & 0.43 & 5.14 & 9 & 1 & 0 & 0 & 0 \\
\hline İB36 & Gülten & 9.7 & 8.88 & 377 & 216 & 43 & 0 & 1 \\
\hline İB37 & Namık Kemal & 6.02 & 8.41 & 1296 & 395 & 42 & 2 & 0 \\
\hline İB38 & Kazım Özalp & 7.72 & 11.86 & 2414 & 463 & 44 & 0 & 22 \\
\hline İB39 & 110 & 12.24 & 11.28 & 1737 & 502 & 13 & 2 & 6 \\
\hline İB40 & 104. & 2.58 & 11.12 & 619 & 113 & 35 & 0 & 1 \\
\hline İB41 & Barış & 5 & 12.59 & 1725 & 250 & 13 & 2 & 5 \\
\hline İB42 & Şirin Berat & 7.5 & 18.56 & 2169 & 224 & 56 & 1 & 2 \\
\hline İB43 & Cömert & 4.41 & 18.08 & 506 & 105 & 26 & 2 & 5 \\
\hline İB44 & Barış & 8.02 & 15.72 & 3014 & 467 & 38 & 9 & 34 \\
\hline İB45 & İnkilap & 5.36 & 16.45 & 1595 & 66 & 42 & 14 & 6 \\
\hline İB46 & Radar & 5.14 & 11.67 & 1202 & 438 & 48 & 6 & 11 \\
\hline İB47 & Yank1 & 3.03 & 13.57 & 224 & 125 & 18 & 1 & 3 \\
\hline İB48 & Sanayi & 7.54 & 10.86 & 1063 & 95 & 6 & 2 & 0 \\
\hline İB49 & Korkmazlar & 14.71 & 10.47 & 1418 & 501 & 38 & 3 & 3 \\
\hline İB50 & Ömer Türkçakal & 8.02 & 6.44 & 1724 & 467 & 40 & 2 & 10 \\
\hline İB51 & Fuariçi & 5.36 & 14.76 & 142 & 66 & 23 & 1 & 1 \\
\hline İB52 & Kanalyolu & 16.96 & 9.36 & 207 & 93 & 16 & 1 & 1 \\
\hline İB53 & Mevlâna & 18.21 & 11.73 & 1163 & 487 & 26 & 2 & 7 \\
\hline İB54 & Ünlüpınar & 6.65 & 12.64 & 515 & 156 & 20 & 4 & 6 \\
\hline İB55 & Elmatepe & 2.69 & 11.46 & 190 & 48 & 30 & 1 & 2 \\
\hline İB56 & Fatma S. Hanım & 21.06 & 11.35 & 2050 & 592 & 54 & 2 & 6 \\
\hline İB57 & Sakıp Sabancı & 7.58 & 11.31 & 539 & 172 & 70 & 1 & 4 \\
\hline İB58 & Ahmet M. Bey & 11.06 & 12.08 & 423 & 165 & 23 & 2 & 4 \\
\hline İB59 & Turgut Reis & 6.7 & 12.84 & 673 & 219 & 19 & 0 & 5 \\
\hline İB60 & Sanayici & 11.42 & 11.62 & 1920 & 206 & 44 & 0 & 2 \\
\hline
\end{tabular}




\begin{tabular}{|c|c|c|c|c|c|c|c|c|}
\hline \multirow{2}{*}{\multicolumn{2}{|c|}{ İzole Ölçüm Bölgeleri }} & \multirow{3}{*}{$\begin{array}{l}\text { Şebeke } \\
\text { uzunluğu } \\
\quad(\mathbf{k m})\end{array}$} & \multirow{3}{*}{$\begin{array}{l}\text { Şebeke } \\
\text { yaşı } \\
\text { (yıl) }\end{array}$} & \multirow{3}{*}{$\begin{array}{c}\text { Abone } \\
\text { sayısı } \\
\text { (adet) }\end{array}$} & \multirow{3}{*}{$\begin{array}{c}\text { Servis } \\
\text { bağlantı } \\
\text { sayısı (adet) }\end{array}$} & \multicolumn{3}{|c|}{ Arıza Sayısı (adet) } \\
\hline & & & & & & \multirow{2}{*}{ Şüpheli } & \multicolumn{2}{|c|}{ Onarilan } \\
\hline No & Konum & & & & & & Şebeke & Abone \\
\hline İB61 & Sultan Murat & 4.42 & 12.69 & 1272 & 212 & 9 & 4 & 3 \\
\hline İB62 & Salkım Söğüt & 9.43 & 8.81 & 1046 & 181 & 37 & 1 & 3 \\
\hline İB63 & Akasyalar & 9.12 & 10.22 & 3357 & 133 & 12 & 0 & 0 \\
\hline İB64 & Hasan Tahsin & 22.19 & 12.06 & 1258 & 245 & 15 & 0 & 2 \\
\hline İB65 & Ağustos & 7.87 & 11.85 & 648 & 93 & 13 & 1 & 0 \\
\hline İB66 & Gemici & 13.57 & 10.82 & 1996 & 173 & 12 & 2 & 1 \\
\hline İB67 & Varlık & 3.21 & 10.84 & 277 & 24 & 8 & 1 & 1 \\
\hline İB68 & Uğur Mumcu & 1.13 & 10.86 & 856 & 592 & 9 & 0 & 1 \\
\hline İB69 & Sepetçi & 21.827 & 15.31 & 891 & 224 & 22 & 0 & 1 \\
\hline
\end{tabular}

\subsection{Basınç Yönetimi}

Su kayıplarını azaltmak için bilinen ve yaygın olarak kullanılan yöntem basınç yönetimidir. Bu çalışmada uygulanan basınç yönetimi ile şebekede ideal işletme basıncı sağlanarak izole bölgelerde akustik dinleme cihazları ile tespit edilemeyen sızıntılar azaltılmıştır. Bu kapsamda izole alt bölgelere basınç ölçüm odaları entegre edilerek su kayıpları önlenmiştir (Şekil 6). Ayrıca bu yöntem aşırı basınca maruz kalan şebekenin yorulmasını önleyerek şebekenin hizmet süresini uzatır.
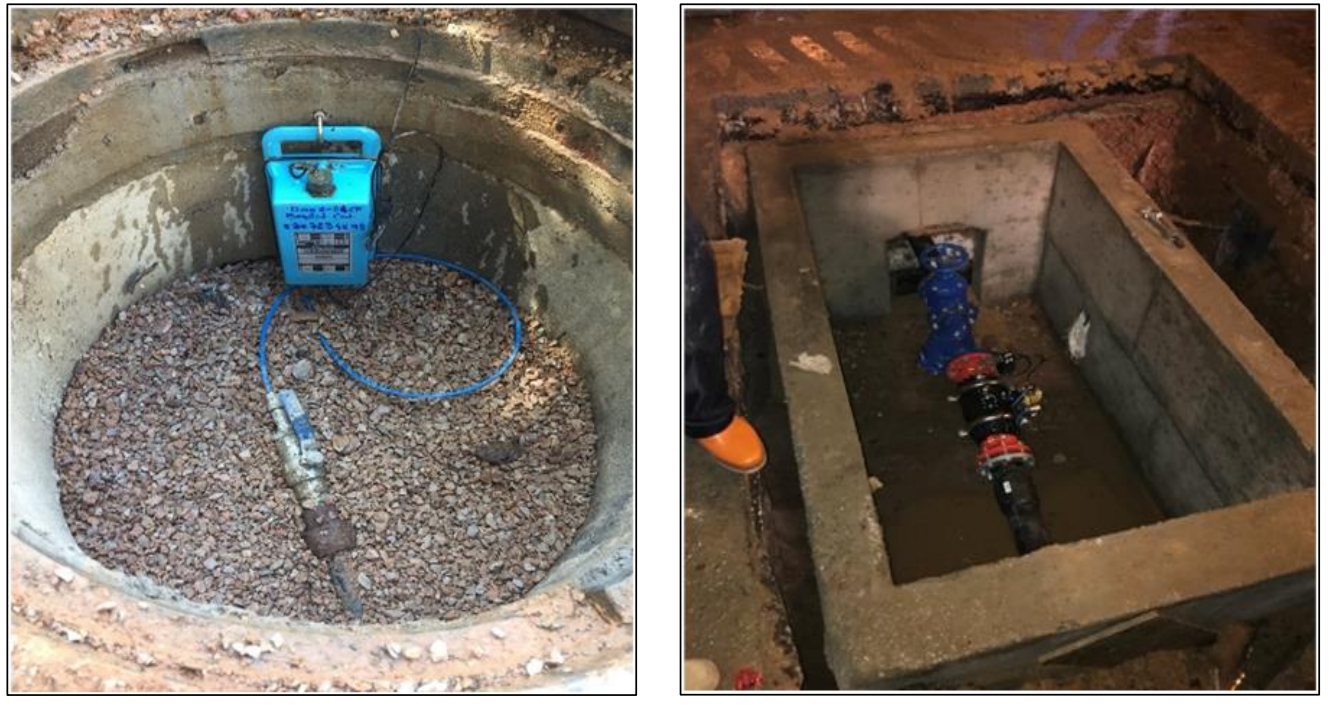

Şekil 6: İzmit su dağıtım sistemindeki basınç ölçüm odaları (Görmüş 2017)

Uygulanan basınç yönetim sistemi ile şebekeye giren, çıkan, kritik basınç değerleri ve minimum gece debileri izlenerek kayıt altına alınmışıtır (Şekil 7).

Şekil 7'de kırmızı renk giriş, turuncu renk çıkış, pembe renk kritik basınçları ve mavi renk ise minimum gece debisini temsil etmektedir. 08 Kasım 2016 yılında işletmeye alınan İB33 için giriș basıncı 72,98 m ve çıkış basıncı 40,15 m olarak ayarlanmıştır. Bölge içinde 11 adet arıza onarılmış olup en son tamir edilen arızadan sonra (kırmızı renkli not) minimum gece debisi 18.30 1/s'den 4.89 l/s'ye düşerek 13.41 l/s kazanç elde edilmiştir. İzole bölgenin ilk kuruluşundan itibaren debiye duyarlı basınç yönetim sistemi uygulanmış ancak abonelerden gelen basınç yetersizliği şikâyeti üzerine sabit basınç yönetim sistemine geçilmiștir.

Benzer şekilde İzmit İlçesi, Sultan Murat Caddesinde bulunan İB61, 23.05.2018 tarihinde devreye alınmış ve şüpheli 9 arızadan onarılan 7 arıza sonucunda minimum gece debisi 13.10 1/s'den 4.14 1/s'ye indirilerek 8.96 l/s' lik kazanç elde edilmiştir. İB61 devreye alındıktan sonra 03.07.2018 tarihinde manuel sabit basınç yönetim sistemi ile işletilmeye başlanmış ve çıkış basıncı $60 \mathrm{~m}$ olacak șekilde hidrolik aktüatör yardımıyla ayarlanmıştır.

05.09.2018 tarihinde izole bölgenin işletme koşulları değiștirilerek zamana duyarlı moda geçilmiștir. Gece 00:00-06:00 saatleri arasında $50 \mathrm{~m}$ ve 06:00-00:00 saatleri arasında $53.92 \mathrm{~m}$ basınç değeri sağlanacak şekilde işletmeye alınmıştır. $\mathrm{Bu}$ bölgenin kritik basıncı ise 39.94 m'dir. 

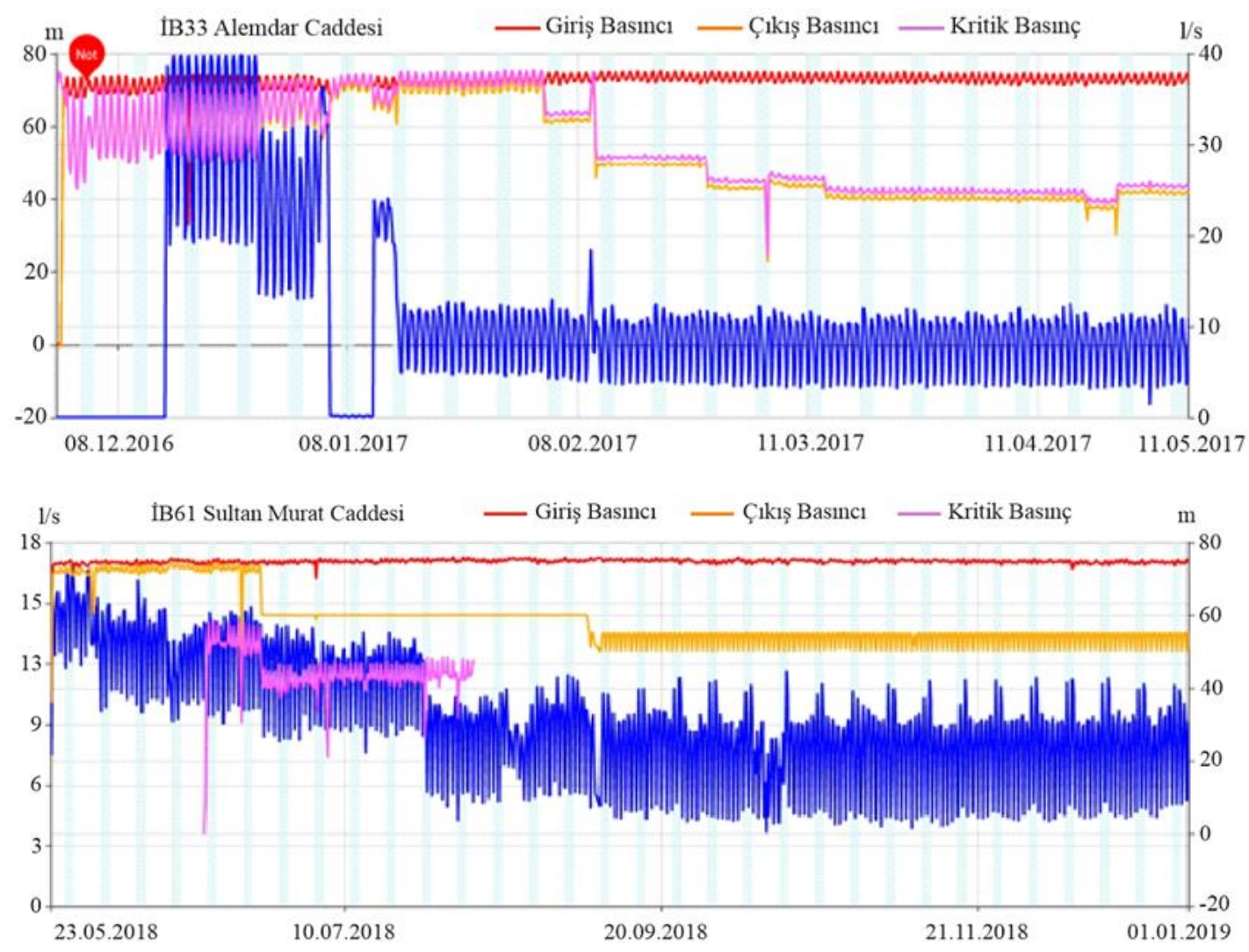

Şekil 7: IB33 ve IB61 için basınç ve debi değişimi

İSU, tüm izole alt bölgelerde debiyi ve basıncı izlemek için Octave marka flanşlı ultrasonic debimetre ve veri kaydeciler kullanmıştır (Şekil 4, Şekil 6). Ayrıca izole bölgelerde minimum gece debisini azaltmak için C-valve marka piston tipli basınç kırıcı vanalar tercih edilmiştir. Çalışma alanındaki her bölgede debi ve basınç SCADA sistemi ile izlenerek su dağıtım sistemi kontrol altına alınmıştır. SCADA sisteminden elde edilen izole bölgelerin basınç değerleri, minimum gece debileri ve tasarruf debileri Tablo 3 'de sunulmuştur.

Hidrolik model sonuçlarına göre seçilen sabit çıkışlı (SÇ), zamana duyarlı (ZD), kritik noktaya göre çalışan ve debiye duyarlı (DD) basınç yönetim sistemleri (BYS) uygulanmıştır (Tablo 3). Çalışma alanında sadece İB41'de basınç yönetim sisteminden faydalanılmamıştır. Sabit çıkışlı basınç yönetimi ile İB33'de giriş basınc1 72,98 m'den 40,15 m'ye kadar düşürülerek minimum gece debisinde 13,41 1/s'lik tasarruf sağlanmıştır. Uygulanan BYS ile İzmit'in su dağıtım sisteminde basınçlar kontrol altına alınarak su kayıpları azaltılmış ve sistemin faydalı hizmet süresinin uzaması sağlanmıştır. İB21'de 60,57 m olan giriş basıncı debiye duyarlı basınç yönetimi ile çıkış basıncı 28,50 m'ye kadar düşürülmüştür. Tasarlanan izole bölgeler arasında maksimum tasarruf 16,57 1/s ile İB21'de gerçekleşmiştir. İstenilen zaman aralıklarında basıncın ayarlanmasına izin veren zamana duyarlı basınç yönetim sistemi kullanılarak İB61'de basınç 74,42 m'den 53,92 m'ye kadar indirgenmiş ve debide 8,96 1/s'lik kazanım gerçekleşmiştir. ZD basınç yönetim sisteminde basınç kırıcı vana ile birlikte bir kontrolör cihazı kullanılmıştır. İB41 dışındaki tüm bölgelerde şebekede izin verilen minimum servis basıncı kritik noktada ihlal edilmemiş ve şebekenin en üst noktasındaki abonenin su ihtiyacını sağlamak için gerekli olan kritik basınca dikkat edilmiştir. BYS ile basınçlar düşürülerek ideal işletme basıncı sağlanırken abone taleplerinin karşılanmasına özen gösterilmiştir.

Tablo 3'de sunulan İB3, İB6, İB35 ve İB63'de akustik dinleme cihazları ile arıza tespit edilememiş ve doğrudan basınç yönetim sistemi uygulanmıştır. Bu yöntem ile minimum gece debilerinde sırasıyla 0,4 1/s, 0,79 1/s, 0,64 1/s ve 1,34 1/s'lik tasarruf sağlanmıştır. Su dağıtım sistemlerinde sadece basınç yönetim sistemi uygulamaları ile de su kayıplarının azaltılabileceği görülmektedir.

İdareler basınç yönetimi uygulayarak sızmaları ve arızaları önemli ölçüde azaltabilirler. Ancak basınç kırıcı vanaların periyodik bakımlarının sürekli olarak yapılması ve pislik tutucularının temizlenmesi gerekir. Özellikle ana şebeke hatlarında yaşanan uzun süreli arızalar nedeni ile tekrar şebekeye su verildiği zaman tüm BKV ayarları uzman personeller tarafından kontrol edilmelidir.

Bakım haricindeki BKV kontrolleri idarelerin işletme maliyetlerini artırmasına neden olur. İçme suyu depo besleme alanlarının tamamen birbirlerinden ayrılarak kat ayrım sınırlarının oluşturulması ile de mevcut sistemin basınç yönetimi sağlanabilir. Ayrıca arazi eğimi fazla olan bölgelerde maslak depoların inşa edilmesi ile birlikte doğal olarak şebeke basınçları düşürülebilir. Böylece basınç kırıcı vana sayılarında ve bakım kaynaklı işletme maliyetlerinde azalmalar gerçekleşebilir. 
Tablo 3: Basınç değerleri ve minimum gece debileri

\begin{tabular}{|c|c|c|c|c|c|c|c|c|}
\hline \multicolumn{2}{|c|}{$\begin{array}{l}\text { İzole Ölçüm Bölgeleri } \\
\end{array}$} & \multirow{2}{*}{ BYS Tipi } & \multicolumn{3}{|c|}{ Basınc (m) } & \multicolumn{2}{|c|}{ Minimum Gece Debisi (1/s) } & \multirow{2}{*}{$\begin{array}{c}\text { Tasarruf } \\
(1 / \mathbf{s})\end{array}$} \\
\hline No & Konum & & Giriş & Çıkış & Kritik & Başlangıç & Bitiş & \\
\hline İB1 & Ersoylu & SÇ & 77.33 & 75.03 & 75.03 & 0.39 & 0.18 & 0.21 \\
\hline İB2 & Gazenfer Bilge & ZD & 81.98 & 75.93 & 26.47 & 9.56 & 5.33 & 4.22 \\
\hline İB3 & Cam & ZD & 121.21 & 49.99 & 30.19 & 0.72 & 0.32 & 0.40 \\
\hline İB4 & Levent & SÇ & 40.31 & 29.92 & 32.35 & 1.91 & 1.63 & 0.28 \\
\hline İB5 & Arızl1 & SÇ & 101.60 & 35.08 & 35.08 & 3.44 & 3.37 & 0.07 \\
\hline İB6 & Akpınar & SÇ & 40.00 & 30.18 & 30.18 & 2.35 & 1.56 & 0.79 \\
\hline İB7 & Sezer & SÇ & 50.55 & 50.08 & 50.08 & 2.30 & 1.46 & 0.84 \\
\hline İB8 & Akif & SÇ & 42.39 & 24.91 & 24.91 & 0.71 & 0.69 & 0.02 \\
\hline İB9 & Kavaklar & $\mathrm{ZD}$ & 50.76 & 32.82 & 31.60 & 3.50 & 2.24 & 1.26 \\
\hline İB10 & Kalemcioglu & DD & 61.03 & 34.38 & 32.88 & 11.72 & 8.89 & 2.83 \\
\hline İB11 & Bayrak & DD & 74.53 & 31.68 & 24.48 & 7.56 & 6.54 & 1.02 \\
\hline İB12 & Arda & DD & 54.84 & 34.06 & 34.06 & 3.04 & 2.66 & 0.38 \\
\hline İB13 & Dinamik & DD & 60.57 & 30.58 & 27.64 & 1.89 & 1.09 & 0.80 \\
\hline İB14 & Zengin & $\mathrm{ZD}$ & 32.61 & 29.50 & 30.26 & 8.49 & 4.99 & 3.50 \\
\hline İB15 & Zengin & DD & 35.30 & 27.08 & 28.65 & 3.68 & 2.86 & 0.82 \\
\hline İB16 & Doruklar & SÇ & 35.84 & 27.08 & 23.88 & 1.33 & 0.77 & 0.57 \\
\hline İB17 & Okur & SÇ & 59.45 & 37.70 & 35.30 & 4.10 & 2.62 & 1.48 \\
\hline İB18 & Ziya Gökalp & DD & 60.67 & 44.23 & 39.00 & 18.92 & 12.61 & 6.31 \\
\hline İB19 & Baycan & DD & 52.63 & 39.98 & 34.63 & 13.67 & 9.67 & 4.00 \\
\hline İB20 & Badem & SÇ & 58.15 & 42.95 & 36.00 & 7.32 & 2.16 & 5.16 \\
\hline İB21 & Türbebayırı & DD & 60.67 & 28.50 & 48.20 & 37.61 & 21.04 & 16.57 \\
\hline İB22 & Uygar & SÇ & 73.92 & 43.37 & 26.53 & 5.62 & 3.15 & 2.47 \\
\hline İB23 & Musa Kazım & $\mathrm{ZD}$ & 62.96 & 48.86 & 37.18 & 2.52 & 1.64 & 0.88 \\
\hline İB24 & Eski Hastane & SÇ & 32.04 & 30.15 & 30.53 & 4.33 & 3.93 & 0.40 \\
\hline İB25 & Narlık Yokuşu & SÇ & 46.66 & 38.89 & 23.72 & 5.62 & 4.76 & 0.86 \\
\hline İB26 & Sila & $\mathrm{ZD}$ & 72.70 & 34.22 & 34.22 & 0.93 & 0.69 & 0.24 \\
\hline İB27 & Korniş & SÇ & 70.90 & 67.77 & 42.86 & 2.71 & 1.57 & 1.14 \\
\hline İB28 & Sadettin Yalım & SÇ & 43.78 & 36.58 & 26.98 & 3.12 & 2.23 & 0.90 \\
\hline İB29 & İnönü & DD & 53.19 & 34.10 & 27.26 & 6.81 & 3.69 & 3.11 \\
\hline İB30 & Eski Hamam & DD & 65.60 & 29.57 & 28.41 & 6.42 & 1.33 & 5.08 \\
\hline İB31 & Acisu & SÇ & 68.27 & 41.19 & 34.55 & 12.61 & 6.69 & 5.92 \\
\hline İB32 & İnönü & SÇ & 61.56 & 47.03 & 21.28 & 4.30 & 1.51 & 2.79 \\
\hline İB33 & Alemdar & SÇ & 72.98 & 40.15 & 40.06 & 18.30 & 4.89 & 13.41 \\
\hline İB34 & İstiklal & DD & 65.72 & 50.50 & 30.93 & 3.74 & 2.19 & 1.55 \\
\hline İB35 & Seka Hastanesi & SÇ & 72.60 & 50.06 & 50.06 & 2.86 & 2.22 & 0.64 \\
\hline İB36 & Gülten & $\mathrm{SCC}$ & 46.37 & 35.06 & 35.06 & 3.30 & 2.20 & 1.10 \\
\hline İB37 & Namık Kemal & SÇ & 59.64 & 52.16 & 36.00 & 17.50 & 11.31 & 6.19 \\
\hline İB38 & Kazım Özalp & SÇ & 40.56 & 35.03 & 35.03 & 4.63 & 2.49 & 2.14 \\
\hline İB39 & 110 & $\mathrm{ZD}$ & 51.03 & 43.76 & 43.76 & 4.68 & 3.77 & 0.91 \\
\hline İB40 & 104. & SÇ & 55.90 & 45.25 & 33.12 & 1.83 & 0.53 & 1.31 \\
\hline İB41 & Barış & - & - & - & - & 24.47 & 15.42 & 9.06 \\
\hline İB42 & Şirin Berat & DD & 77.66 & 53.03 & 29.90 & 13.76 & 10.60 & 3.16 \\
\hline İB43 & Cömert & SÇ & 63.39 & 39.99 & 35.00 & 5.21 & 2.36 & 2.85 \\
\hline İB44 & Barış & SÇ & 6.00 & 5.57 & 5.57 & 17.32 & 10.75 & 6.57 \\
\hline İB45 & İnkilap & DD & 67.03 & 58.04 & 33.00 & 8.88 & 5.23 & 3.64 \\
\hline İB46 & Radar & SÇ & 30.36 & 25.86 & 25.86 & 3.50 & 2.33 & 1.17 \\
\hline İB47 & Yank1 & DD & 43.56 & 37.18 & 30.17 & 2.34 & 1.91 & 0.43 \\
\hline İB48 & Sanayi & $\mathrm{ZD}$ & 52.97 & 19.99 & 4.47 & 2.45 & 0.96 & 1.49 \\
\hline İB49 & Korkmazlar & DD & 98.37 & 41.28 & 32.15 & 6.63 & 3.76 & 2.86 \\
\hline İB50 & Ömer Türkçakal & DD & 45.13 & 34.14 & 33.08 & 6.76 & 3.77 & 2.99 \\
\hline İB51 & Fuariçi & DD & 41.51 & 30.00 & 25.42 & 2.95 & 1.93 & 1.02 \\
\hline İB52 & Kanalyolu & DD & 85.50 & 43.29 & 35.05 & 32.42 & 16.89 & 15.53 \\
\hline İB53 & Mevlâna & SÇ & 40.79 & 39.69 & 31.49 & 5.56 & 1.57 & 4.00 \\
\hline İB54 & Ulupınar & $\mathrm{ZD}$ & 78.98 & 69.68 & 24.86 & 5.27 & 1.97 & 3.30 \\
\hline İB55 & Elmatepe & SÇ & 79.49 & 59.83 & 25.35 & 1.77 & 0.72 & 1.05 \\
\hline İB56 & Fatma S. Hanım & SÇ & 74.54 & 66.62 & 21.52 & 14.11 & 11.67 & 2.44 \\
\hline İB57 & Sakıp Sabancı & DD & 68.26 & 48.34 & 48.34 & 0.67 & 0.56 & 0.11 \\
\hline İB58 & Ahmet M. Bey & SÇ & 52.52 & 52.06 & 21.52 & 2.62 & 1.64 & 0.98 \\
\hline İB59 & Turgut Reis & DD & 57.67 & 34.35 & 46.25 & 2.41 & 1.15 & 1.25 \\
\hline İB60 & Sanayici & SÇ & 58.88 & 49.79 & 37.56 & 3.28 & 2.83 & 0.45 \\
\hline İB61 & Sultan Murat & $\mathrm{ZD}$ & 74.62 & 53.92 & 39.94 & 13.10 & 4.14 & 8.96 \\
\hline İB62 & Salkım Söğüt & DD & 58.99 & 47.13 & 33.65 & 6.97 & 3.85 & 3.12 \\
\hline İB63 & Akasyalar & $\mathrm{SÇ}$ & 62.28 & 52.41 & 52.30 & 3.89 & 2.55 & 1.34 \\
\hline
\end{tabular}




\begin{tabular}{|c|c|c|c|c|c|c|c|c|}
\hline \multicolumn{2}{|c|}{ İzole Ölçüm Bölgeleri } & \multirow{2}{*}{ BYS Tipi } & \multicolumn{3}{|c|}{ Basınç (m) } & \multicolumn{2}{|c|}{ Minimum Gece Debisi (1/s) } & \multirow{2}{*}{$\begin{array}{c}\text { Tasarruf } \\
(\mathbf{l} / \mathbf{s})\end{array}$} \\
\hline No & Konum & & Giriş & Çıkış & Kritik & Başlangıç & Bitiş & \\
\hline İB64 & Hasan Tahsin & $\mathrm{SC}$ & 39.33 & 30.21 & 12.96 & 8.21 & 4.79 & 3.42 \\
\hline İB65 & Ağustos & SÇ & 40.09 & 35.10 & 28.06 & 2.84 & 1.09 & 1.75 \\
\hline İB66 & Gemici & $\mathrm{SCC}$ & 32.60 & 31.90 & 30.00 & 4.32 & 2.36 & 1.96 \\
\hline İB67 & Varlik & SÇ & 47.90 & 30.25 & 30.25 & 0.71 & 0.22 & 0.49 \\
\hline İB68 & Uğur Mumcu & SÇ & 22.56 & 20.15 & 26.65 & 4.10 & 1.24 & 2.86 \\
\hline İB69 & Sepetçi & SÇ & 135.66 & 135.30 & 30.00 & 3.60 & 1.89 & 1.71 \\
\hline Toplam & & & & & & & & 192.48 \\
\hline
\end{tabular}

$\mathrm{Bu}$ çalışmada fiziki kayıpları azaltmak için ilk önce aktif sızıntı kontrol aktiviteleri uygulanarak tespit edilen arızaların onarılması ile minimum gece debileri azaltılmıştır. Ancak İB3, İB6, İB35 ve İB63'de akustik dinleme cihazları ile arızalar tespit edilemeyip su kayıpları önlenememiştir. Daha sonra tespit edilemeyen arızalardan kaynaklı sızmaları engellemek için basınç yönetim sistemi uygulanmıştır. Bu yöntemle de minimum gece debileri SCADA sistemi ile izlenerek belli seviyelere düşürülmüş̧ür. İB41'de olduğu gibi her zaman şebekelerde basınç yönetimi uygulanamayabilir. Bu neden ile su dağıtım sistemlerinde kayıpları azaltmak için aktif sızıntı kontrol metotlarının ve basınç yönetim sistemlerinin birlikte uygulanması daha etkili olacaktır.

Fiziki kayıpları azaltmak için yapılan bu çalışmaların yanı sıra idari kayıpları azaltmak için izole bölge içinde ekonomik ömrü dolmuş (10 yılı tamamlamış) su sayaçları uzaktan okuma sistemine entegre olabilecek akıllı sayaçlar ile değiş̧irilmiştir. İzmit genelinde 2015 ve 2019 yılları arasında toplam 136.785 adet sayaç İSU tarafından yenilenmiş̧ir. Böylece sayaç ölçüm hatalarından kaynaklı tahakkuk kayıpları minimize edilerek 2019 yılı sonunda idari kayıplar \% 4,16 seviyelerine kadar düşürülmüştür. Su idareleri sayaçlarını yenileyerek idari kayıplarını fiziki kayıplara göre daha kolay azaltabilirler.

Su kayıplarını azaltmak için İzmit'in su dağııım şebekesinde yapılan çalışma sonunda 2019 yılında toplam 192,48 1/s'lik su tasarrufu sağlanmıştır. Şebekenin yaklaşık \%50'sinin kontrol edilmesi ve izlenmesi ile 2014 yılında su kaybı oranı $\% 45,40$ ve kayıp miktarı $16.083 .184 \mathrm{~m}^{3}$ seviyelerinde iken bu oran 2019 y1lında \%29,50'ye ve kayı miktarı ise $9.252 .382 \mathrm{~m}^{3}$ seviyelerine kadar düşürülmüştür.

\section{Sonuçlar}

Bu çalışmada bir su dağııım sistemindeki kayıpları önlemek için uygulanan, aktif sızıntı kontrol metotları, basınç yönetim sistemi ve sayaç yenileme aktivitelerinin etkili oldukları görülmektedir. Mevcut su dağıtım sistemlerinin küçük, ölçülebilir ve yönetilebilir izole bölgelere ayrılmaları için, öncelikle hidrolik model tasarımlarına ihtiyaç duyulmuştur. Bu izole bölgelerde akustik dinleme cihazları ile, ihbar edilmeyen sızıntıların tespiti yapılarak, tekniğine uygun şekilde onarılmaları sonucu minimum gece debileri düşürülebilmiştir. Su idareleri tespit edilemeyen sızıntıları engellemek için basınç yönetim sistemini uygulayabilirler. Bu yöntem sayesinde ideal işletme basıncı sağlanarak, arıza sayıları ve sızmalar büyük oranda azaltılabilir. Ayrıca boru içindeki basıncın düşürülmesi ile şebekenin hizmet süresinin uzaması da sağlanmaktadır. Bununla birlikte idareler su dağıtım sistemlerini farklı izole bölgelere ayırmaları sonrasında, basınç ve minimum gece debisini SCADA sistemi ile izlemeleri ve arıza tespit çalışmaları ile fiziki kayıplarını önemli ölçüde önleyebilirler. Fiziki kayıpların azaltılmasının idari kayıplara göre çok daha zor olduğu bu araştırmada bir kez daha görülmektedir. Bunlarla birlikte idari kayıpların azaltılması için tercih edilen en etkili yöntem sayaç ölçüm hatalarının minimize edilmesi olmuştur. Bu amaçla aktif bir şebekedeki faydalı ömrünü tamamlamış su sayaçları yenileri ile değiş̧tirilmiştir. İdarelerin su kayıpları ile mücadelesinde bu yöntemler ile birlikte literatürde yer alan benzer diğer yöntemlerinde birlikte veya ayrı ayrı kullanılabilmeleri mümkündür. Bu çalışmada yukarıda sıralanan tüm yöntemler bir arada uygulanarak, İzmit'in su kaybı, beş yıl içerisinde \%45,40'dan \%29,50 seviyelerine indirilmiştir. İSU, Kocaeli genelinde benzer yöntemleri kullanarak 2023 yılında su kaybını \%25 seviyesine indirebilmek için planlamalarını sürdürmektedir.

\section{Kaynaklar}

Arabacı E., Dursun Ş., (2019), İçme suyu altyapı sistemlerinde hidrolik modelleme: Konya örneği, Ulusal Çevre Bilimleri Araştırma Dergisi, 2(4), 177-185.

AWWA (2003), Best practice in water loss control: improved concepts for 21 st century water management. American Water Works Association. https://www.awwa.org/Portals/0/AWWA/ETS/Resources/WLCFlyerFinal.pdf?ver=2015-02-10-083650-287, [Erişim 10 Şubat 2015].

Aydogdu M., Firat M., (2015), Estimation of failure rate in water distribution network using fuzzy clustering and LS-SVM methods, Water Resourse Management, 29, 1575-1590.

Boztaş F., Özdemir Durmuşçelebi F.M., Firat M., (2019), Analyzing the effect of the unreported leakages in service connections of water distribution networks on non-revenue water, International Journal of Environmental Science and Technology, 16(8), 43934406.

Davis S.E., (2005), Residental water meter replacement economics, In: Proceedings of IWA Leakage 2005 Conference, ss. 1-10. 
Durmuşçelebi F.M., Özdemir Ö., Fırat M., (2020), District metered areas for water loss management in distribution systems, Sigma Journal of Engineering and Natural Sciences, 38(1), 149-170.

Farley M., (2003), Non revenue water-international best practice for assessment, monitoring and control, In: 12th annual CWWA water, wastewater \& solid waste, ss. 1-18.

Farley M., Trow S., (2003), Losses in water distribution network, IWA Publishing, London, 296ss.

Gonelas K., Kanakoudis V., (2016), Reaching economic leakage level through pressure management, Water Science and Technology: Water Supply, 16(3), 756-765.

Güngör M., Yarar U., Cantürk Ü., Fırat M., (2019), Increasing performance of water distribution network by using pressure management and database integration, Journal of Pipeline Systems Engineering and Practice, 10(2), doi:10.1061/(ASCE)PS.19491204.0000367.

Görmüş Y., (2017), İzmit ilçesi su kayıplarının azaltılması projesi, 1. içme suyu temin ve dağıtım sistemlerindeki su kayıplarının kontrolü çalıştayı ve eğitimi, 26-27 Ekim, Malatya, Türkiye.

İSU (2019), Kocaeli Su ve Kanalizasyon İdaresi Genel Müdürlüğü, 2019 Yılı Faaliyet Raporu, Kocaeli, Türkiye.

Kanakoudis V., Muhammetoglu H., (2014), Urban water pipe networks management towards non-revenue water reduction: Two case studies from Greece and Turkey, Clean - Soil, Air, Water, 42(7), 880-892, doi:10.1002/clen.201300138.

Koşucu M.M., Sarı Ö., Demirel M.C., Kıran S., Yılmaz A., Aybakan A., Albay E., Özgür Kırca V.Ş., (2021), Gerçek zamanlı basınç yönetimiyle su dă̆ıtım şebekesinde su kaybının azaltılması, Teknik Dergi, 32(1), 10541 - 10564.

Lambert A.O., (2002), International report: Water losses management and techniques, In Water Science and Technology: Water Supply, 2,1-20.

Lambert A., (2003), Assessing non-revenue water and its components: a practical approach, Water, 21, 50-51.

Lambert A., Morrison J.A.E., (1996), Recent developments in application of 'bursts and background estimates'concepts for leakage management, Water and Environment Journal, 10(2), 100-104.

Lambert A., Fantozzi M., Thornton J., (2013), Practical approaches to modeling leakage and pressure management in distribution systems - progress since 2005, 12th International Conference on Computing and Control for the Water Industry, CCWI2013, 2-4 September, Perugia, Italy.

Liemberger R., Wyatt A., (2019), Quantifying the global non-revenue water problem, Water Science and Technology: Water Supply, 19(3), 831-837.

Morrison J., Tooms S., Rogers D., (2007), District metered areas: Guidance notes, International Water Association (IWA), Specialist Group on Efficient Operation and Management, Water Loss Task Force, 96 ss.

Mutikanga H.E., Sharma S.K., Vairavamoorthy K., (2013), Methods and tools for managing losses in water distribution systems, Journal of Water Resources Planning and Management, 139(2), 166-174.

Nicolini M., Giacomello C., Scarsini M., Mion M., (2014), Numerical modeling and leakage reduction in the water distribution system of Udine, In Procedia Engineering, 70, 1241-1250.

OSIB, (2017), T.C. Orman ve Su İşleri Bakanlığı, 2. Ormancılık ve Su Şurası, 5-7 Mayıs, Afyonkarahisar.

Rahman A., Wu Z.Y., (2018), Multistep simulation-optimization modeling approach for partitioning water distribution system into district meter areas, Journal of Water Resources Planning and Management, 144(5), doi:10.1061/(asce)wr.1943-5452.0000927.

Samir N., Kansoh R., Elbarki W., Fleifle A., (2017), Pressure control for minimizing leakage in water distribution systems, Alexandria Engineering Journal, 56(4), 601-612.

Thornton J., Sturm R., Kunkel G., (2008). Water Loss Control. McGraw Hill Professional, 632 ss.

Yılmaz S., Özdemir Ö., Fırat M., (2019), Gelir getirmeyen su oranının azaltılması için optimum sayaç değiştirme süresinin hesaplanması, Frrat Üniversitesi Mühendislik Bilimleri Dergisi, 31(2), 423-430. 